\title{
Interactions of tumor cells with dendritic cells: balancing immunity and tolerance
}

\author{
MV Dhodapkar, ${ }^{*, 1}$ KM Dhodapkar ${ }^{2}$ and AK Palucka ${ }^{3}$
}

Dendritic cells (DCs) are antigen-presenting cells specialized to initiate and maintain immunity and tolerance. DCs initiate immune responses in a manner that depends on signals they receive from pathogens, surrounding cells and their products. Most tumors are infiltrated by DCs. Thus, interactions between DCs and dying tumor cells may determine the balance between immunity and tolerance to tumor cells. In addition, DCs also display non-immunologic effects on tumors and the tumor microenvironment. Therefore, improved understanding of the cross talk between tumor cells and DCs may suggest new approaches to improve cancer therapy.

Cell Death and Differentiation (2008) 15, 39-50; doi:10.1038/sj.cdd.4402247; published online 19 October 2007

During homeostatic turnover, each day billions of cells undergo death to be replaced by newly differentiated progeny. This balance is critical to the maintenance of organ size and tissue architecture. Malignancy is characterized by altered growth of a malignant clone resulting in disrupted tissue architecture ${ }^{1}$ Malignant cells are also genetically abnormal, with aberrant production of proteins, lipids and sugars that can in principle, be recognized by the immune system.

Tumor cells dying either naturally or as a result of anti-tumor therapies are rapidly cleared by phagocytes. Several types of phagocytes, including macrophages, dendritic cells (DCs) and neutrophils are thought to play a role in the removal of the dying corpse. This process potentially exposes the immune system to self (non-mutated) as well as mutated unique antigens. ${ }^{2}$ Of the various phagocytes involved in the removal of dying cells, DCs are the professional antigen-presenting cells (APCs) that play a central role in the initiation and regulation of immune responses. DCs regulate both the innate (e.g. macrophages, granulocytes and natural killer (NK) cells) and the adaptive (e.g. T and B cells) immunity., ${ }^{3,4}$ DCs can present captured antigens to $\mathrm{T}$ cells in an immunogenic or tolerogenic fashion. The nature of T-cell response induced by DCs largely depends on signals the DCs receive from surrounding cells.

DCs are found to infiltrate several types of tumors in both human and mice..$^{3,5-8}$ Therefore, understanding how tumor cells interact with DCs may have major implications for the development of immunity or tolerance against tumor cells. In this review, we will discuss recent insights into interactions between DCs and tumor cells in the context of DC biology. We will also discuss how these newly unraveled pathways might be harnessed for improved immunotherapy of cancer.

\section{Dendritic Cells as Critical Antigen-Presenting Cells in Tumor Immunity}

DCs are APCs that initiate and regulate immune responses (Figure 1). ${ }^{3}$ Their central role in regulating immunity and tolerance is emphasized by their ability to control both innate and adaptive lymphocytes. Peripheral tissue antigen-loaded DCs migrate through the afferent lymphatics into the draining lymph nodes where they present processed protein and lipid antigens to $\mathrm{T}$ cells via both classical (major histocompatibility complex (MHC) class I and class II) and non-classical (CD1 family) antigen-presenting molecules. Non-activated (immature) DCs present antigens to T cells, which in the absence of appropriate costimulation leads to tolerance. 9,10 Upon encounter with pathogens or other 'danger'-associated stimuli, such as cytokines, products of damaged tissues or innate lymphocytes, DCs undergo a process of activation (maturation), wherein they acquire the capacity to activate immunity. ${ }^{11-13}$ This process of activation has profound effects on $\mathrm{DC}$ biology and function. It includes translocation of $\mathrm{MHC}$ to

\footnotetext{
${ }^{1}$ Laboratory of Tumor Immunology and Immunotherapy, The Rockefeller University, New York, NY, USA; ${ }^{2}$ Laboratory of Cellular Physiology and Immunology, The Rockefeller University, New York, NY, USA and ${ }^{3}$ Baylor Institute of Immunology Research and Baylor Research Institute, Dallas, TX, USA

${ }^{*}$ Corresponding author: M Dhodapkar, Laboratory of Tumor Immunology and Immunotherapy, The Rockefeller University, 1230 York Avenue, New York, NY 10021 , USA. Fax: 212327 7119; E-mail: dhodapm@ @ockefeller.edu

Keywords: dendritic cells; apoptosis; immunity; tolerance

Abbreviations: AC, apoptotic cells; APC, antigen presenting cells; CLR, C-type lectin receptors; CR3, complement receptor 3; CRD, carbohydrate recognition domains; CTL, cytolytic T cells; DAMP, damage associated molecular patterns; DC, dendritic cells; HMGB1, high-mobility box 1; IFN, Interferon; ITAM, immune tyrosine activation motif; ITIM, immune tyrosine inhibitory motif; LC, langerhans cells; MF, macrophage; MHC, major histocompatibility complex; NK, natural killer cells; NLR, nucleotide oligomerization domain-like receptors; PS, phosphatidylserine; RAGE, receptor for advanced glycation end products; TGF- $\beta$, transforming growth factor beta; TIRAP, Toll IL1 receptor adaptor protein; TLR, Toll-like receptors; TNF, tumor necrosis factor; TRAM, TRIF-related adaptor molecule; TRIF, TIR domain-containing adaptor protein inducing interferon; Tregs, regulatory T cells; TSLP, thymic stromal lymphopoietin

Received 20.8.07; revised 13.9.07; accepted 17.9.07; Edited by G Kroemer; published online 19.10.07
} 


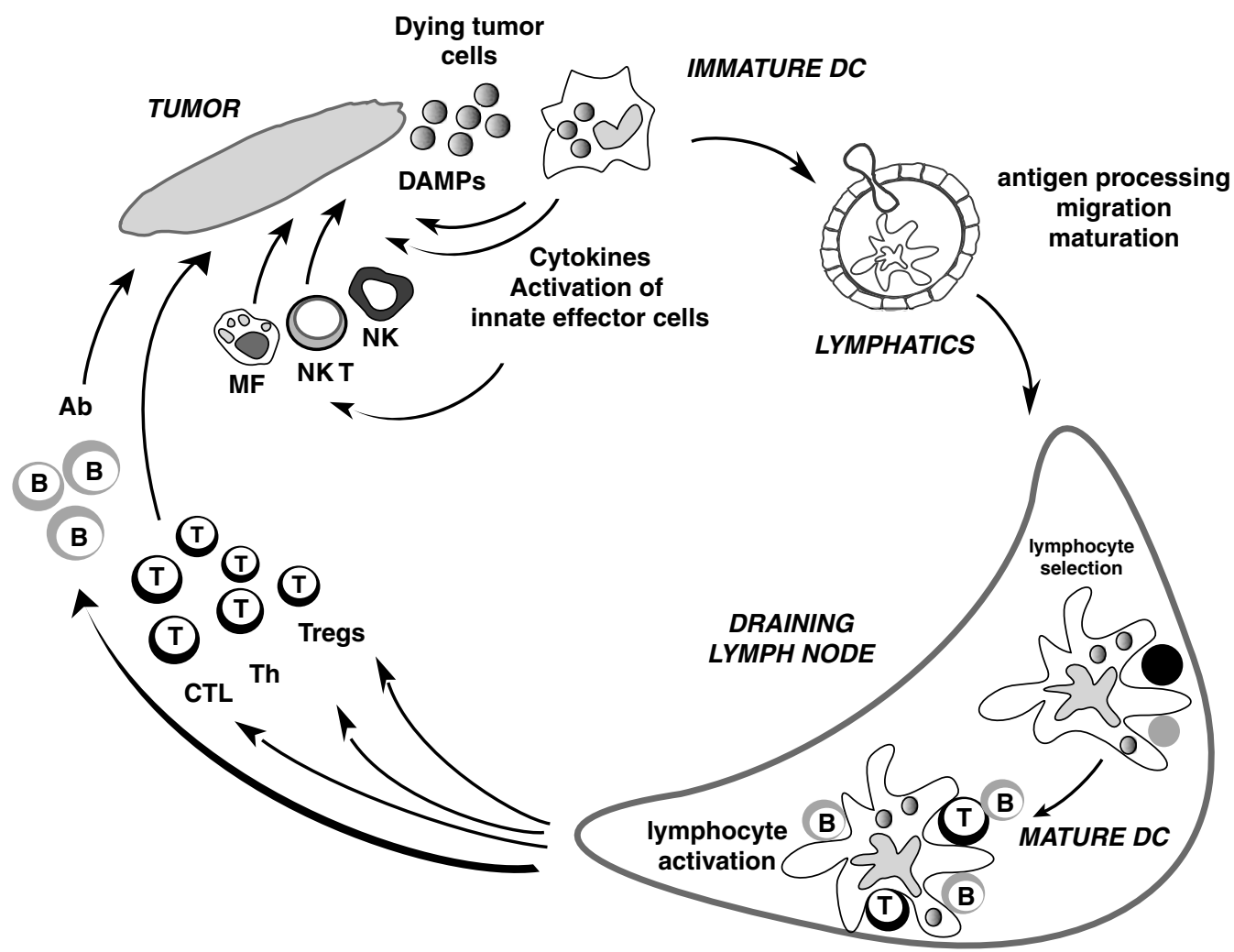

Figure 1 The life cycle of dendritic cells in the context of tumor immunity. Circulating precursor DCs enter tissues as immature DC where they can encounter dying tumor cells and their products. This can lead to the recognition of dying tumor cells via DAMPs, capture of dying tumor cells and migration towards draining lymph nodes as well as secretion of cytokines. Cytokines secreted by DCs in turn activate effector cells of innate immunity such as eosinophils, macrophages and NK cells. DCs migration towards secondary lymphoid organs might be associated with their simultaneous activation (maturation) by the products of dying cells such as uric acid or HMGB1 or by cytokines in autocrine or paracrine fashion. These activated migratory DCs that enter lymphoid organs display pMHC complexes, which allow selection of rare circulating antigen-specific $T$ lymphocytes. Activated T cells help DCs for their terminal maturation, which allows lymphocyte expansion and differentiation leading to generation of effector cells and antibodies. However, tumor microenvironment and/or dying tumor cells might inhibit DC maturation leading to the generation of Tregs rather than effector cells. It remains to be determined whether tumor antigens can also reach draining lymph nodes without involvement of peripheral tissue DCs and be captured by lymph node-resident DCs. ${ }^{164}$ Abbreviations: DAMP, damage-associated molecular patterns; NKT, natural killer T; MF, macrophage; Ab, antibody; Th, Thelper cells; CTL, cytolytic T cells

the cell surface, increased expression of costimulatory molecules, changes in motility and acquisition of dendrites, which among others create an enormous surface to present antigen and interact with lymphocytes. ${ }^{14,11}$ Several stimuli, such as signals from inflammatory cytokines, innate lymphocytes, CD40 ligand and pattern recognition receptors (or combinations thereof), have been shown to mediate DC activation, and in some instances, license them to induce immunity. ${ }^{15-17}$ However, the nature of specific T-cell responses generated may differ between different stimuli for DC activation. Some activation stimuli that mediate phenotypic changes associated with DC activation may not suffice to elicit protective T-cell immunity. ${ }^{18,19}$

Tumors by themselves are poor APCs. Studies in murine models have suggested that the generation of protective antitumor immunity depends on the presentation of tumor antigens by bone marrow-derived APCs, most likely by DCs. $^{20}$ Indeed, DCs can efficiently present captured tumor antigens not only on MHCll, as is the case for other APCs, but also $\mathrm{MHCl}$, a process termed as 'cross presentation., 21,22 This ability of DCs to cross present antigen from dying cells may be critical for the induction of anti-tumor immunity in vivo. ${ }^{22}$ Under steady state, this pathway may also contribute to the induction of tumor and tissue-specific tolerance. ${ }^{23}$ Accordingly, defects in uptake of apoptotic cells (ACs) have been implicated in the development of autoimmunity. ${ }^{24}$ Induction of T-cell immunity in response to dying tumor cells in vivo in mice requires a DC activation stimulus, which can be delivered via innate lymphocytes, CD40 or Toll receptor ligands. ${ }^{12}$

Importantly, DCs are not only efficient at stimulating helper and cytolytic T cells (CTLs), but can also generate regulatory $\mathrm{T}$ cells (Tregs) both in vitro and in vivo. ${ }^{9}$ Initial studies demonstrated that immature DCs can lead to the activation of IL10-producing Tregs. ${ }^{25,26}$ Recent studies have shown that activated DCs are also efficient at activating both naturally occurring and antigen-specific FoxP3 + CD4 + CD25+ Tregs. ${ }^{27-29}$ Generation of Tregs by activated DCs might actually permit resolution of anti-microbial immune responses. ${ }^{30}$ The capacity of DCs to induce Tregs is significantly enhanced by cytokines such as transforming growth factor beta (TGF- $\beta$ ) or IL10. ${ }^{31,32}$ Uptake or tumor cells by DCs, in the context of immune suppressive cytokine milieu, may therefore promote the induction of tumor-specific Tregs. A growing body of evidence points to an important role for Tregs as an obstacle to tumor immunity. ${ }^{33,34}$ Uptake of dying tumor cells by DCs may play a critical role in the induction and 
maintenance of tumor-specific Tregs in vivo and deserves further study.

An additional layer of complexity is imparted by the different DC subsets that reside in different tissues (or are recruited to them) that may carry different degrees of specialization with regard to activation of different components of the immune system. Such diversity might allow the adaptive immune system to mount functionally distinct types of responses. This is important because the type of immune response itself can be a matter of life of and death. For example, in leprosy, the tuberculoid form of the disease is characterized by a 'type 1' response and low morbidity, but the lepromatous form which is characterized by a 'type 2 ' response, often kills the host. ${ }^{35}$ Thus, DCs and their subsets may serve as a link between innate and adaptive immunity by integrating the information from the environment to direct the quality of induced adaptive immunity. ${ }^{15}$

In addition to adaptive immunity, DCs are also efficient in their ability to interact with and activate innate lymphocytes such as NK cells. ${ }^{36}$ Due to their ability to regulate diverse aspects of the immune response, DCs are an attractive candidates for vaccination against cancer, either by injection of DCs generated ex vivo from bone marrow progenitors or blood precursors and loaded with antigens; or by their specific targeting in vivo with anti-DC antibodies fused to antigen. ${ }^{37,38}$ Understanding how tumor cells may impact the biology and function of DCs in the tumor microenvironment, therefore, has direct implications for exploiting DCs for cancer immunotherapy.

\section{Interaction of DCs with Dying Tumor Cells}

In view of the important role of DCs in immune regulation, several studies have attempted to examine the interaction of dying cells with DCs. ${ }^{39}$ This interaction involves several steps beginning with the recognition and uptake of dying cells, processing of the cargo, activation of DCs and eventually, the activation of innate and adaptive lymphocytes. An emerging theme from these studies is that the interaction between these cells and its functional consequences involves several players and pathways highly conserved through evolution. Importantly, many of the steps are regulated by a balance between positive and negative signals (Table 1). Activation of each step often requires not just the provision of a positive stimulus, but also the removal of a negative one. The existence of multiple pathways creates the potential for synergy and pattern recognition through combinatorial diversity. Some molecules impact more than one aspect of these interactions and, to some degree, there may be a division of labor. Below we discuss and exemplify these emerging themes.

Recognition and uptake of dying cells by DCs. Dying cells have been postulated to engage several mechanisms to signal the innate immune system for disposal of the corpse (Figure 2). Three types of signals are operative: (i) 'find me', (ii) 'eat me' and (iii) 'stay away.'

(i) 'Find me' signals are soluble factors, such as lysophosphatidylcholine, and might induce migration of phagocytes to ACs. ${ }^{40}$
Table 1 Some examples of putative opposing signals that regulate immunity to dying cells

\begin{tabular}{|c|c|c|c|}
\hline Process & Promotes & Inhibits & References \\
\hline Recognition & $\begin{array}{l}\text { PS and PS } \\
\text { bridging signals } \\
\text { Heat-shock } \\
\text { proteins } \\
\text { CD36, CR3, } \\
\text { c-mer, integrins } \\
\text { Lyso-PC }\end{array}$ & $\begin{array}{l}\text { CD47 } \\
\text { CD31 }\end{array}$ & $40-44$ \\
\hline Uptake & $\begin{array}{l}\text { Integrins, } \\
\text { activating } \mathrm{Fc}_{\mathrm{c}} \mathrm{R} \\
\text { CD36 }\end{array}$ & CD47 & $42,45-47$ \\
\hline DC activation & $\begin{array}{l}\text { Activating } \\
\text { Fc } \gamma \text { Rs } \\
\text { TLRs }\end{array}$ & $\begin{array}{l}\text { CR3 } \\
\text { c-mer } \\
\text { Inhibitory } \\
\text { FcRs } \\
\text { ?CLRs }\end{array}$ & $42,48-50$ \\
\hline $\begin{array}{l}\text { Phagosome } \\
\text { maturation }\end{array}$ & $?$ TLR & $?$ & $51-54$ \\
\hline $\begin{array}{l}\text { Antigen } \\
\text { processing/ } \\
\text { presentation }\end{array}$ & $\begin{array}{l}\text { TLR, Activating } \\
\text { Fc } \gamma \text { Rs, CLRs }\end{array}$ & $\begin{array}{l}\text { Inhibitory } \\
\text { FcRs }\end{array}$ & $55-58$ \\
\hline
\end{tabular}

(ii) 'Eat me' signals are usually membrane bound and serve as markers for phagocytes to recognize and ingest ACs. These include alterations in cell surface phospholipid composition with exposure of phosphatidylserine (PS), alterations in cell surface charge or expression of specific molecules. ${ }^{41}$ A number of receptors expressed on immature DCs such as $\alpha \mathrm{v} \beta 5$ integrin, complement receptors and $\mathrm{CD} 36$ are thought to be involved in $\mathrm{AC}$ uptake. ${ }^{42,43}$ The exposure of PS is among the bestcharacterized events in the interaction of ACs and DCs. It is possibly mediated by increased phospholipid scrambling and the loss of aminophospholipid translocase activity. ${ }^{41}$ Several bridge molecules that bind to PS and link to DC receptors have also been identified. These include milk fat globulin E8, which binds av integrins; ${ }^{59}$ Gas-6 and protein S, which interact with Mer tyrosine kinase ${ }^{60}$ Another pathway may involve collectin family of pattern recognition molecules (such as C1q, mannose binding lectin and surfactant protein-D), which may bind to calreticulin complexed with CD91 or low-density LRP 1. ${ }^{61-63}$ Furthermore, 'eat me' signals might be indirect, that is, mediated by serum or phagocyte-derived proteins, which can opsonize ACs, and thereby promoting their capture. ${ }^{64-67}$ Complement receptors, scavenger receptors as well as Fc receptors can be involved here as well and each will be discussed further hereunder.

(iii) 'Stay away' (or 'do not eat me') signals may be critical to prevent the uptake of activated but live cells, which might express positive signals such as calreticulin. ${ }^{45}$ These serve as negative regulators and include CD47 or CD31. 46

Capture of ACs leads to activation of several signaling pathways. The downstream convergence of several pathways 


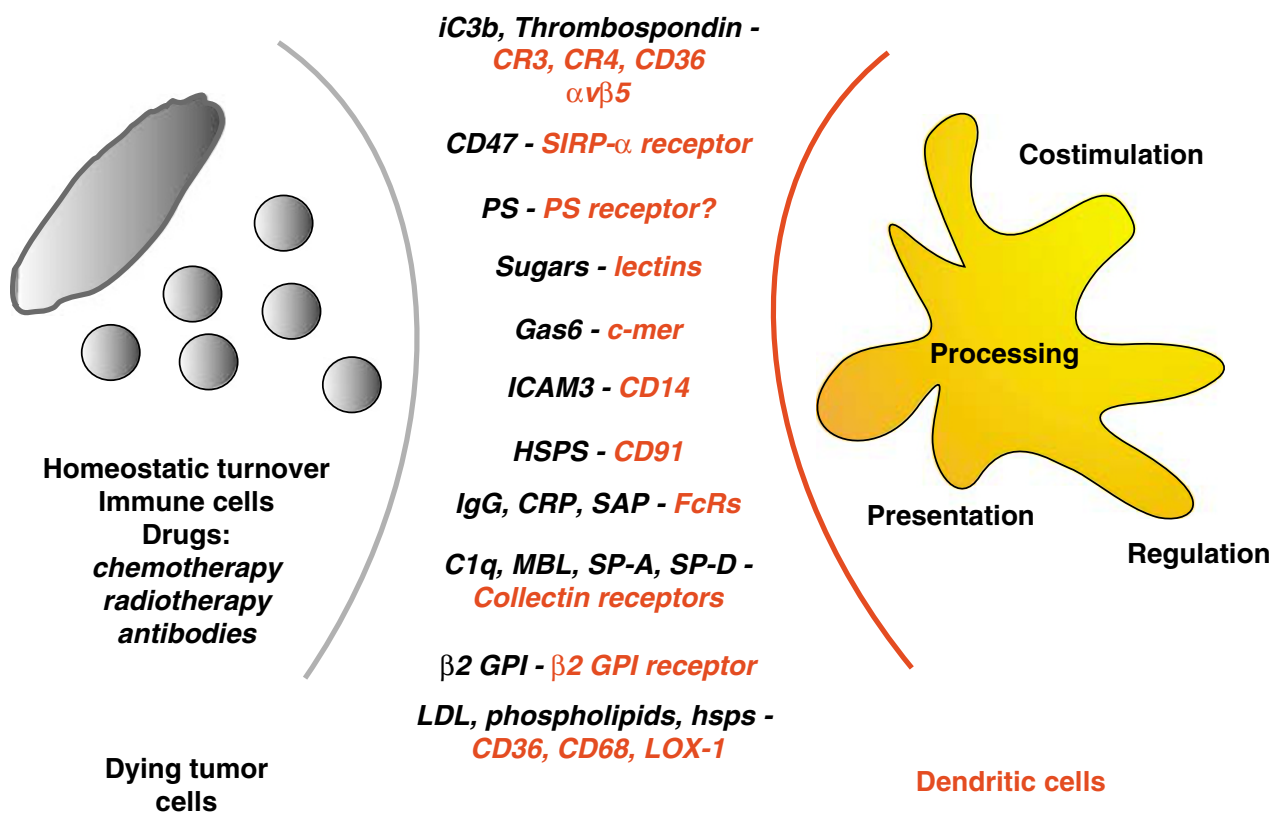

Figure 2 Some phagocyte surface receptors and their putative ligands implicated in the recognition of dying cells. Dying tumor cells, generated either as a result of tissue turnover or the anti-tumor activity of immune cells or therapy, express several ligands that can be recognized by DCs. Ligands expressed by dying cells can function as 'eat me' (e.g. PS) or 'stay away' (do not eat me) signals (for example CD47). In turn, DCs express an armamentarium of receptors that are involved in the recognition and capture of dying tumor cells. This will ultimately lead to tumor antigen processing and presentation to T cells. Additional factors such as expression of costimulatory molecules by DCs and/or cytokines secreted by DCs may regulate the final outcome of antigen presentation and generation of immunity or tolerance

may involve activation of the low-molecular weight GTPase Rac1, which is required for uptake and cytoskeletal rearrangement. $^{68}$ For example, Rac1 can be activated via the formation of Crkll-Dock180 complex by both by PS engagement, as well as by intergrins. ${ }^{59}$ This pathway appears to be evolutionarily conserved and for example, bears considerable homology to activation of ced-10 in Caenorhabditis elegans. CD47 can serve as an example of the control elements in the cell death recognition/uptake pathway. Interactions of SIRP $\alpha$ on phagocytes with CD47 leads to activation of Srchomology-containing tyrosine phosphatase-1 (SHP-1) and therefore inhibit Src family kinases. ${ }^{45}$ Uptake of dying cells therefore may require not just one (or more) positive signal(s), but also the loss of a negative signal.

\section{Regulation of processing and presentation of dying} cells. The pathways for recognition and uptake of dying cells discussed above are not unique to DCs, but also operative in other phagocytes, particularly macrophages. However, DCs and macrophages differ substantially in antigen processing and presentation, and the capacity to prime $\mathrm{T}$ cells. ${ }^{69}$ Therefore, the immunologic consequences of antigen uptake are expected to be quite distinct for macrophages versus DCs. One of the critical differences between DCs and macrophages may be differential lysosomal proteolysis of the phagocytosed antigen. ${ }^{70-72}$ While macrophages contain high levels of lysosomal proteases and rapidly degrade proteins, DCs exhibit limited proteolysis, favoring antigen persistence and presentation. DCs are also much more efficient at loading exogenous antigens on $\mathrm{MHCl}$ for cross-presentation of captured antigens to CD8 + killer T cells. ${ }^{21,73}$
Importantly, capture of dying tumor cells is ultimately linked with DC activation, which in turn will determine the type of ensuing T-cell immunity. Several receptors have been shown to be important for antigen uptake and presentation of phagocytosed dying cells by DCs. Of these the major receptors include complement and $\mathrm{Fc} \gamma$ receptors, mer family kinases, lectin receptors and toll receptor pathways. The underlying theme appears to be that engagement of certain pathways (for example mer, or complement receptor3, inhibitory FcRs) may mediate tolerance, whereas the engagement of others (for example Toll-like receptors (TLRs), activating FcRs) promote immunity. At least in some instances, such as the uptake of immune complexes or opsonized tumor cells, the same ligand binds both to activating and inhibitory receptors.

Role of complement and scavenger receptors. ACs are frequently opsonized by complement component iC3b generated as a result of low level complement activation. Binding of iC3b-opsonized ACs to its receptor, complement receptor 3 (CR3) on APCs has been implicated in tolerance induced by dying cells. ${ }^{64}$ Indeed, DCs exposed to ACs opsonized with $\mathrm{iC} 3 \mathrm{~b}$ are inhibited from activation in response to stimuli such as CD40L and LPS. Recently, two studies with murine bone marrow DCs, as well as human monocytederived DCs have shown that engagement of CR3 leads to suppressive effects on DC function, mediated in part via release of TGF- $\beta$ and possibly IL10 in some settings. ${ }^{48,49}$ Recent studies also suggest a division of labor between various receptors for dying cells. For example, whereas $\alpha \mathrm{v} \beta 5$ had a significant effect on phagocytosis, CR3 had a more 
dominant effect on the suppression of DC activation. ${ }^{48}$ Another receptor implicated in immune-suppressive effects of $\mathrm{ACs}$ is the scavenger receptor CD36, which binds to oxidized phospholipids and thrombospondin. ${ }^{74}$ However, the mechanisms by which these receptors lead to the induction of tolerizing DC states still needs to be clarified. It is also notable that most of the current data regarding the effects of individual ligands/receptors are based on in vitro experiments and the relative importance in vivo remains to be clarified.

Role of mer tyrosine kinase. Recently, the mer/Axl/Tyro3 receptor tyrosine kinase (RTK) family has been implicated in homeostatic regulation of APC activation. ${ }^{75}$ Mice lacking all three RTKs develop hyperactivated DCs, and macrophages, which drive lymphoproliferation and systemic autoimmunity. ${ }^{75}$ Mice lacking Mer-TK expression also develop a lupus-like syndrome and have defective clearance of ACs. ${ }^{44,76} \mathrm{~A}$ ligand for mer-TK is growth-arrestspecific gene 6 (Gas-6), which binds to PS expressed on ACs. ${ }^{77}$ Mer-TK-deficient DCs are resistant to AC-induced inhibition of NFkB pathway, suggesting an important role for this pathway in AC-mediated regulation of DC function. ${ }^{50}$ Together these data suggest an important role for this pathway in the regulation of AC-DC interaction and suggest that constitutive engagement of this pathway may be an important control checkpoint for DC activation.

Role of activating/inhibitory $F_{\gamma} \gamma R$ balance. Fc $\gamma R s$ represent one of the best studied receptors for the uptake and targeting of antigens to DCs, either in the form of immune complexes or opsonized dying cells, such as those generated during antibody therapy of cancer. ${ }^{78}$ The $\mathrm{Fc} \gamma \mathrm{R}$ system consists of a balance of activating and inhibitory FcRs, which carry an immune tyrosine activation (ITAM) or inhibitory (ITIM) motif in their cytoplasmic domain, respectively. Human monocytes and DCs express an array of these receptors, including both activating and inhibitory FcRs. ${ }^{79,55}$ Several studies have now shown that antigen uptake in the form of immune complexes or opsonized tumor cells is associated with enhanced antigen presentation by DCs and the generation of antigen-specific $T$ cells. ${ }^{47,80-82}$ Selective blockade of inhibitory $\mathrm{Fc} \gamma$ receptors is associated with DC activation. ${ }^{55}$ DCs from mice deficient in the inhibitory FC $\gamma$ RII have a more activated phenotype. ${ }^{56}$ These data suggest that the balance of activating versus inhibitory FcRs may have a major impact on DC activation in vivo. The ability of IC to enhance antigen presentation depends on the recruitment of syk to the activating FcRs. ${ }^{83}$ Recently, it was shown that selective activation of activating FcRs leads to the induction of a type I interferon response program in human monocytes and monocyte-derived DCs. ${ }^{84}$ The balance of FcR signaling may therefore regulate the level of constitutive type I IFN signaling in myeloid cells. Together these data suggest that the engagement of activating Fc $\gamma$ Rs on DCs by opsonized dying cells may lead to major effects on the biology of DCs and generation of adaptive immunity. Harnessing this pathway may allow the recruitment of adaptive immunity and immunologic memory by antibody therapy of cancer.
Role of C-type lectin receptors. C-type lectin receptors (CLRs) represent a family of calcium-dependent lectins that share primary structural homology in their carbohydrate recognition domains (CRDs). ${ }^{85}$ CLRs bind to self and nonself sugars, including those expressed on tumor cells. Several members of CLR family are expressed on myeloid cells including DCs. Some of the best studied members on myeloid APCs include the mannose receptor, DEC-205, DCSIGN, and Dectin-1, which have endocytic activity. ${ }^{85}$ Signaling pathways engaged by these receptors have not yet been fully defined, however, the functional effects of targeting antigens to these receptors are being elucidated. Much of the work relates to recognition of pathogen-derived ligands, however, it is likely that these receptors are engaged by normal tissues as well as by transformed cells. ${ }^{57}$ For example, targeting antigen to DEC-205 in the steady state in vivo leads to immune tolerance. ${ }^{10,58}$ Targeting DC-SIGN leads to inhibition of TLR-mediated IL12 production and DC maturation. ${ }^{57,86} \mathrm{~A}$ recent study showed that the engagement of Dectin1, which contains a hemi-ITAM motif, leads to induction of Th17 cells via syk- and CARD9-dependent mechanism. ${ }^{87}$ Although the diversity and signaling mediated by these receptors remains to be clarified, engagement of these receptors by tumor cells may have major effects on antigen presentation. Some examples of potential CLR ligands expressed by tumor cells include muc1, which binds to the mannose receptor and galactose-type clectin $^{88}$ and the carcinoembryonic antigen (CEA), which binds to DC-SIGN. ${ }^{89}$

Role of TOLL-like receptors. TLRs are pattern-recognition receptors that mediate the recognition of pathogenassociated molecular patterns. ${ }^{90}$ TLRs initiate signaling via myeloid differentiation primary response gene (MyD88), TollIL1 receptor adaptor protein (TIRAP), TIR domain-containing adaptor protein inducing interferon (TRIF) and TRIF-related adaptor molecule. TLR signaling can lead to the activation of several signaling pathways including mitogen-activated protein kinases (MAPK) such as p38, ERK and JNK, NFkB and interferon response genes pivotal to immune response. Recruitment of TLRs to newly formed phagosomes suggested that this may form a mechanism to monitor the nature of phagocytic cargo. ${ }^{91}$ Current data suggest that TLRs do not serve directly as phagocytic receptors, and abrogation of TLR signaling does not prevent the uptake of TLR containing particles. ${ }^{92}$ TLR signaling may, however, impact the fusion of phagosomes with lysosomes and endosomes, a process collectively termed as 'phagosome maturation'. ${ }^{51}$ One mechanism by which this might occur is p38-MAPKmediated recruitment of Rab family of small GTPases, which are considered as critical regulators of endosomal traffic. However, the impact of TLRs on phagosome maturation is still somewhat controversial and has not been observed in other experimental settings. ${ }^{52}$

Interestingly, an elegant study by Blander and Medzhitov ${ }^{53,54}$ has shown that the engagement of TLR signaling by phagocytic cargo can dramatically impact the MHCll presentation of antigens from that cargo by targeting li degradation. Phagosomes that do not engage TLRs fail to process li and do not accumulate mature $\mathrm{MHCll}$ dimers. It is notable that 
this TLR-mediated control of presentation appears to be phagosome autonomous. In other words, antigen processing within the phagosomes may be uncoupled from the activation status of DCs themselves. One possible mechanism is via compartmentalized assembly of the TLR signaling complex. One mechanism by which TLRs might influence proteolysis and antigen processing might be by relieving negative regulation (e.g. by cystatin $\mathrm{c}$ ), ${ }^{93}$ or inducing optimal phagosomal $\mathrm{pH}$, perhaps by regulating the activities of vacuolar ATPase and the NADPH oxidase NOX2. ${ }^{69,94,95}$

The concept that phagosomes containing TLR ligands might be processed differently provides a subcellular level of self/nonself discrimination, depending on the content of the phagosomal cargo. This process may also be operative in other pathways. For example, after uptake of a mixture of mAbopsonized and non-opsonized dying myeloma cells, only the antigens from the former subset were efficiently presented by human DCs. ${ }^{80}$ Schulz et al. ${ }^{96}$ have shown that murine CD $8 \alpha+$ DCs can be activated by double-stranded RNA present in virally infected dying cells via a TLR3-dependent mechanism. However, this has not yet been demonstrated with human cells, and the human counterpart of CD8 + DCs remains to be clarified. TLR-mediated enhancement of antigen presentation also has major implications for vaccine design. For example, conjugation of TLR ligands with antigen was shown to enhance generation of T-cell responses. ${ }^{97}$

Role of cytokines and other soluble factors. In addition to signals generated from cellular receptors, uptake of dying cells is also associated with altered release of cytokines that can impact the generation of immunity. For example, ACs can specifically inhibit the expression of several cytokines, particularly IL12. ${ }^{98}$ Uptake of ACs can also lead to the production of immune suppressive cytokines such as TGF$\beta .^{99}$ Phagocytosis of microbially infected cells, in contrast, is designed to eliminate pathogens and trigger the inflammatory response, including the production of tumor necrosis factor (TNF), IL1 and IL6. The microenvironment of tumors is already enriched for immune suppressive cytokines such as VEGF, TGF- $\beta$, IL10 and IL13. ${ }^{33}$ Some of these cytokines are produced directly by tumors while others are produced by immune cells recruited to the tumor bed. The pattern of cytokines in the tumor bed may depend on the specific tumor and involved tissue. These cytokines can have a major impact on the nature of $T$ cell response elicited by DCs. For example, TGF- $\beta$ and IL10 may promote the induction of regulatory cells by DCs. ${ }^{31,32}$ The immunologic outcome of uptake of tumor cells by DCs will therefore likely depend on the specific tumor type and its unique microenvironment.

Cell death may also release some proinflammatory molecules. Damage-associated molecular pattern (DAMPs) are largely intracellular molecules that can act extracellularly to initiate inflammation. ${ }^{100}$ Several receptors, including TLRs and receptor for advanced glycation products, probably play a role in recognition of DAMPs. Several molecules such as highmobility box1 (HMGB1), ${ }^{101}$ heat-shock proteins, ${ }^{102}$ purine metabolites such as uric acid, ${ }^{103}$ matrix components such as hyaluronan ${ }^{104}$ and heparan sulfate, may play a role in the recognition of damage-associated cell death. Nucleotide oligomerization domain-like receptors (NLRs) are a family of germline-encoded pattern recognition receptors that allow the host to respond rapidly to several pathogenic microorganisms. ${ }^{105} \mathrm{~A}$ breakthrough in the field was the identification of inflammasomes, which are NLR containing large multiprotein complexes that recruit inflammatory caspases and trigger their activation. ${ }^{106}$ At least four pathogen-sensing inflammasomes have been identified and at least one of them (cryopyrin/NALP3), also mediates the recognition of endogenous danger signals such as uric acid. ${ }^{107}$ In a recent study, activation of IL1R-MyD88 pathway was shown to be critical for neutrophil but not monocyte response to inflammation induced by necrotic cells. ${ }^{108}$ Therefore, both the nature of the soluble factor(s), as well as the responding cell type may determine the outcome of response to dying cells.

An important recent insight is the crosstalk between the release of danger-associated soluble mediators such as HMGB1 and TLR-mediated activation of APCs in the immune response to dying cells and immune complexes. For example, Apetoh et al. ${ }^{109}$ recently demonstrated that both HMGB1 and TLR4-MyD88 signaling pathways were required for generating immune responses against dying tumor cells. Tian et al. ${ }^{110}$ demonstrated that HMGB1 was an essential component of DNA-containing immune complexes that mediated activation of plasmacytoid DCs (pDCs), through a TLR9/MyD88 pathway involving receptor for advanced glycation end products (RAGE). Although the specific receptors for HMGB1 remain somewhat controversial and require further study, these studies do point to the emerging importance of the crosstalk between different 'sensing' mechanisms, such as TLRs, Fc $\gamma$ receptors, RAGE and possibly other receptors for determining immunity to dying cells and immune complexes.

Integration of signals. As discussed above, DCs must integrate (often opposing) signals from several pathways and receptors, including the uptake- and pattern-recognition receptors and inflammatory/anti-inflammatory cytokines. Although the current knowledge of signaling pathways engaged by dying cells is evolving, data suggest a role for several pathways, including the Jak-STAT pathway, NFkB pathway and TLR-dependent signaling in regulating immune activation. ${ }^{50,111,112}$ A critical pathway in this regard may be the Jak-STAT pathway, as activation of STAT3 in tumor infiltrating DCs can promote tolerance in several models. ${ }^{113}$ Alternately, activation of type I IFN signaling and STAT1 may promote induction of immunity. Engagement of some pathways such as Mer-TK may promote the inhibition of NFkB activation. ${ }^{50} \mathrm{~A}$ greater degree of complexity emerges from the recognition of crosstalk between these pathways, such as between the FcR pathway and type I IFN signaling. ${ }^{84}$ Furthermore, the responsiveness of DCs (or a certain subset thereof) to engagement of a certain pathway may depend on several factors including the strength of the signal, as well as the basal state of signaling in that cell. ${ }^{111}$

\section{Role of DC Subsets in the Interaction with Dying Tumor Cells}

Just as lymphocytes, DCs are composed of distinct subsets with common and unique functions. Different subsets may 
mediate distinct functions in response to dying cells. ${ }^{114}$ Indeed, the requirement for immunogenic or tolerogenic presentation of tissue-derived antigens may be different for different subsets of DCs. For example, uptake of ACs by a subset of B220-PDCA1- lymphoid DCs in the mouse can result in the production of type I IFN by a TRIF- and MyD88independent pathway, as well as the ability to prime CD4+ and CD8 + T-cell responses to antigens derived from dying cells. ${ }^{115}$ In contrast, GM-CSF-derived myeloid murine DCs can phagocytose ACs, but generally do not induce immunity in the absence of type I IFN signaling, such as that initiated by Toll receptors. Different subsets of DCs may also be specialized to activate different arms of the immune system. ${ }^{116}$ For example, mouse splenic CD8 + DCs, but not CD8- subset were shown to be able to cross-present antigens in vitro and in vivo. ${ }^{117,118}$ CD8 + DCs express relatively higher level of proteins involved in $\mathrm{MHCl}$ presentation, and may be specialized for presenting antigens to CD8 + $\mathrm{T}$ cells, whereas the CD8- DC subset may be more specialized to present antigens on $\mathrm{MHCll}$ to CD4 T cells. ${ }^{116}$ Pathways that regulate the recognition and processing of antigens from dying cells in these subsets may differ, and therefore the nature of immune response generated may depend not only on the nature of signals from the dying cells, but also the nature of the processing APC. Unfortunately, at present, it remains difficult to translate the findings from mouse DC subsets to humans as the human counterparts of some of the murine DC subsets (e.g. CD8 + DCs) remain elusive.

Nonetheless, different subsets of DCs exist in humans as well. Much alike in the mouse, in the human two major DC pathways are found, that is, plasmacytoid DCs and myeloid DCs. ${ }^{119}$ Two types of myeloid DCs are found in the human skin: Langerhans cells (LCs) in the epidermis, and interstitial DCs (intDCs) in the dermis. ${ }^{120}$ Cells with corresponding phenotypic and functional profiles can also be generated by culturing human CD34 + HPCs with GM-CSF and TNF. ${ }^{121}$ These subsets display different phenotypes and biological functions. For example, intDCs, but not LCs, express nonspecific esterases. ${ }^{122}$ This is important because different enzymatic activity might yield different peptides that will be presented to $\mathrm{T}$ cells as distinct $\mathrm{pMHC}$ complexes eventually generating different repertoires. IntDCs, but not LCs, express IL10 and induce the differentiation of naïve B cells into IgMsecreting plasma cells. ${ }^{122,123}$ Accordingly, intDCs activate CD4 + follicular helper $\mathrm{T}$ cells. In contrast, LCs are particularly efficient at inducing high-avidity cytotoxic CD8 ${ }^{+}$ $T$ cells. These recent findings led us to propose that intDCs (dermal DCs) preferentially induce humoral immunity, whereas LCs preferentially induce cellular immunity (Klechevsky et al, submitted).

Functional differences apply also to monocyte-derived DCs and different cytokines skew the in vitro differentiation of monocytes into DCs with different phenotypes and function. Thus, when activated (for example by GM-CSF) monocytes encounter IL4, they will yield IL4-DCs. ${ }^{124}$ By contrast, after encounter with IFN- $\alpha$, thymic stromal lymphopoietin (TSLP), TNF or IL15, activated monocytes will differentiate into DCs with distinct functional properties, and termed as IFN-DCs, ${ }^{125}$ TSLP-DCs, ${ }^{126,127}$ TNF-DCs or IL15-DCs, ${ }^{128}$ respectively. For example, myeloid DCs that contain LCs, that is, IFN-DCs or IL15-DCs ${ }^{129}$ are more efficient in priming high affinity tumorspecific CTLs.

The existence of DC subsets and their functional plasticity might actually provide a framework for handling the diverse phenotypes of dying tumor cells and generating diverse immune responses (Figure 3). By analogy to how DC handle microbes, the recognition of ACs might be regulated by expression of unique receptor by each DC subset that recognize a unique ligand on ACs. This selective recognition may lead to a specific type of immune response, for example humoral immunity when ACs are taken up by intDCs or cellular immunity when ACs are taken up by LCs. However, DCs and their subsets display a great degree of plasticity in which case a DC may express a combination of receptors that may permit a particular DC to interact with different types of ACs, which will be dictated by the type of ligand expressed on ACs. Thus, DCs may be able to generate different types of responses to different ACs. Finally, a dying tumor cell expressing different ligands might interact with distinct types of DCs thereby eliciting an immune response that will results from an interplay between the two DC subsets. For example, dying tumor cell might be recognized and captured by myeloid DCs, but it may also interact with neighboring plasmacytoid DCs and trigger them to secrete type I interferon. This in turn will activate myeloid DCs and facilitate generation of cellular immunity. ${ }^{130}$

\section{Interactions of DCs with Living Tumor Cells}

Although most of the attention regarding the interaction of tumor cells with DCs to date has focused on dying tumor cells (and its immunologic outcome), it is now increasingly clear that DCs may also have more direct interactions with living cells. DCs can acquire antigen from living cells for cross presentation, by a process termed 'nibbling', which may be a distinct mechanism of antigen uptake. ${ }^{131,132}$ Interactions between tumor cells and DCs may render DCs into tolerogenic TGF- $\beta$-secreting cells that induce CD4 + CD25+ Tregs. ${ }^{133}$ However, interactions of DCs and tumor cells may also have several non-immunologic consequences. There is already an extensive body of literature about the role of tumorassociated macrophages in promoting tumor progression. However, as discussed above, DCs are functionally and biologically distinct from macrophages. Recent studies from two groups have shown that DCs may have direct effects on survival and clonogenicity of human tumors such as myeloma. ${ }^{134-136}$ DCs have also been implicated in promoting angiogenesis in human tumors. DCs may promote angiogenesis both by serving as direct progenitors to tumorassociated neoangiogenesis, as well as by the secretion of proangiogenic cytokines. ${ }^{137,138}$ Here again, different subsets of DCs may play distinct roles in modifying the tumor microenenvironment. Certain subsets of DCs may mediate a tumorprotective effect. TLR-mediated activation of DCs may enable effector function with tumoricidal properties. ${ }^{139}$ Certain subsets of DCs seem to have overlapping phenotype with NK cells. ${ }^{140}$ For example, a subset of murine DCs termed interferon producing killer DCs (IKDCs) were shown to play an important role in tumor immune surveillance. ${ }^{141-143}$ DCs have also been 


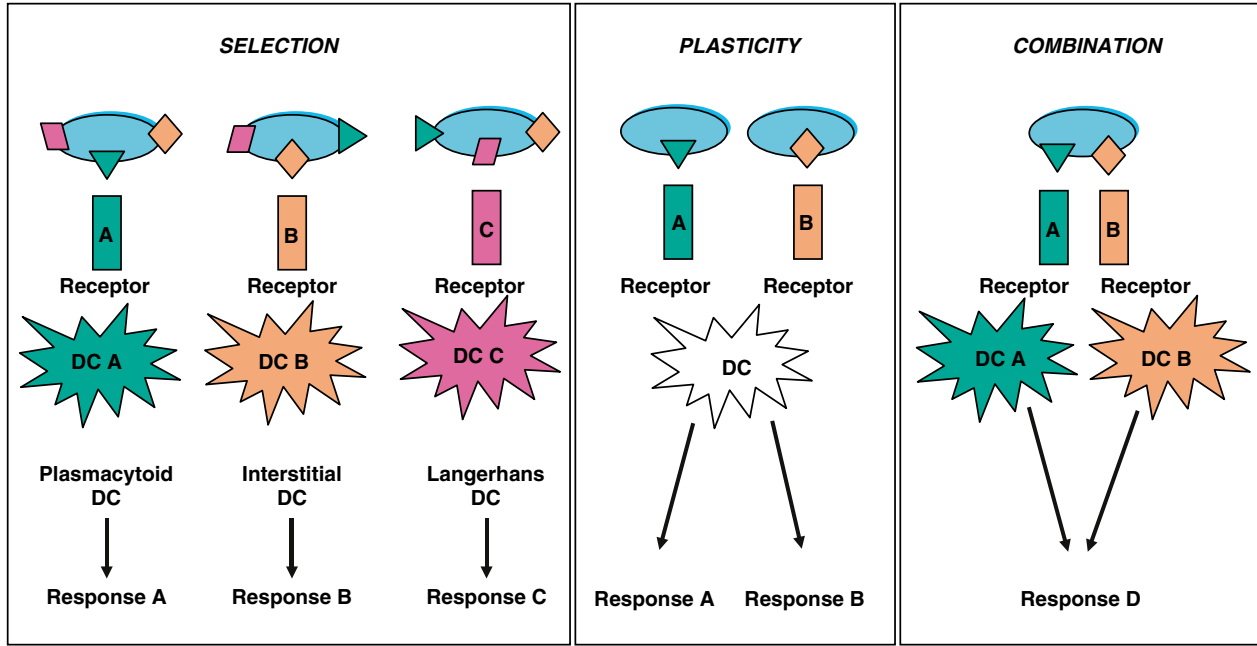

Dying tumor cells

Figure 3 The molecular response of DCs and their subsets to dying tumor cells. Several models can be envisioned: (i) selection, where different apoptotic tumor cells or different ligands expressed on an apoptotic tumor cell target distinct DC subsets through a unique set of receptors, (ii) plasticity, where different apoptotic tumor cells or their ligands act through different receptors on the same DC leading to generation of qualitatively different immune responses, and (iii) a dying tumor cell may target two distinct DC subsets, leading to a mixed response through a combination of signals

shown to be capable of inducing tumor cell death by other mechanisms such as Fas or nitric oxide-mediated interactions. ${ }^{144}$ Taken together, these emerging data suggest that different DC subsets may have both tumor-promoting as well as tumor-suppressive properties in vivo. This can be exemplified by the demonstration that breast cancer instructs DCs to induce CD4 + T cells secreting IL13 and promote cancer development by mediating DC polariziation. ${ }^{5}$ Thus, improved understanding of DCs in the tumor bed, particularly in human tumors is therefore needed to better harness the anti-tumor effects (and avoid the protumor effects) of these cells.

\section{Implications for Tumor Immunotherapy}

DC activation as a marker of immunogenic tumor cell death. The possibility that cell death induced by different chemotherapies might have different consequences for the immune system was first suggested in a landmark study by Casares et al., ${ }^{39,145}$ who showed induction of tumor immunity in mice after anthracycline (but not mitomycin) treatment of tumors. A growing body of data now suggests that the immunogenicity of dying cells may be linked to their ability to activate DCs. ${ }^{146-148}$ Uptake of myeloma cells killed by bortezomib (a proteasome inhibitor), but not those killed by dexamethasone or $\gamma$-irradiation led to activation of DCs. ${ }^{147}$ Surprisingly, uptake of bortezomib killed tumor cells was sufficient to induce tumor-specific $T$ cells in culture without the need for an exogenous activation stimulus. The delivery of activating stimulus from bortezomib killed tumor cells to DCs was mediated by the expression of hsp90 on the surface of dying cells. Bortezomib killed murine tumors also seem to deliver a DC activation signal, although the underlying mechanism has not yet been investigated in this system. ${ }^{149}$
Interestingly, Obeid et al. ${ }^{146}$ have recently demonstrated that induction of protective anti-tumor immunity in mice in response to tumor cell death induced by anthracyclines was linked to the induction of calreticulin (another heat shock protein) on the surface of dying murine tumor cells. Immunostimulatory activity of tumor cells enriched in heat shock proteins after induction of hyperthermia has also been observed in some animal models as well as with human cells in culture. ${ }^{150-152}$ This is also in accordance with murine studies showing that cell surface hsps represent a distinct immunogenic signal (relative to soluble hsps) and promotes the development of autoimmunity. ${ }^{153,154}$ Together, the common theme from these independent observations is that the exposure of certain heat shock proteins on the surface of dying cells may be a marker for immunogenic forms of cell death and deliver an activating stimulus to DCs.

Chemotherapy. The finding that some chemotherapies induce an immunogenic form of cell death in some cell types has major implications for both understanding and improving the results with chemotherapy, as well as combining it with immune-based approaches. Activation of adaptive immunity has the potential to impact the durability of clinical responses due to the recruitment of immunologic memory. For example, the possibility that immune-based mechanisms may underlie the clinical effects of bortezomib may help understand the observed correlation of vasculitic skin rash with clinical response to bortezomib in lymphoma, as well as the observations that the clinical responses may be delayed by several months in many patients with follicular lymphoma. ${ }^{148,155}$ One important issue for harnessing the potentially immunogenic property of chemotherapy induced cell death may be the need for tumor-specific targeting. This may be accomplished via coupling to anti-tumor antibodies, 
or via advances in nanotechnology. Indeed, targeting 'immunogenic drugs' selectively to tumor cells in vivo may serve as a cancer vaccine. Such a strategy might also have the additional advantage that it does not require prior knowledge of antigens expressed by tumor cells, and would be specific for the spectrum of antigens expressed by the patient's own tumor. Improved understanding of the mechanisms of immunogenic cell death might eventually allow us to not only better harness these properties of some agents, but may also allow us to modify cell death induced by other agents. In the end, it may be valuable to view chemotherapy and immunotherapy not as antagonistic, but as synergistic partners for improving outcome in cancer. ${ }^{156}$

It is worth noting that even though certain forms of chemotherapies may be able to mediate an immunogenic form of cell death, this may not suffice for the generation of protective or therapeutic anti-tumor immunity. This may be because the tumor microenvironment presents several challenges for the immune system, including the presence of Tregs (which may be further induced). ${ }^{33,34}$ The tumor bed also contains several other immune-suppressive elements such as suppressive cytokines (for example VEGF, IL10 and TGF- $\beta$ ) and cells (such as myeloid suppressor cells). ${ }^{33,34}$ Another potential obstacle may be that most chemotherapies fail to kill cancer stem cells, which are inherently resistant to such therapies. This may be important, as recent studies have suggested that immune responses to antigens derived from cancer stem cells are associated with improved outcome in human cancer. ${ }^{157}$ Therefore generating clinically meaningful immunity even with immunogenic chemotherapy will require attention to overcoming these obstacles.

Antibody therapy. Monoclonal antibodies have already proven to be among the most successful forms of new anti-tumor therapies in the last decade. However, these agents also provide underappreciated opportunities for immunization against cancer. ${ }^{158,159}$ Monoclonal antibody therapy-promoted cell death can directly cause tumor destruction, and subsequent antigen uptake, presentation by DCs and related professional APCs, leading to adaptive T-cell-mediated immune responses. Monoclonal antibodies can be engineered to mediate improved antibody-dependent cytotoxicity, which should enhance antigen presentation and T-cell activation. ${ }^{82}$ This can be accomplished by increasing antibody affinity for tumor antigen targets, or by manipulating antibody $F_{c} \gamma$ domains to increase their affinity for $F c \gamma$ receptor(s). ${ }^{160}$ As discussed above, it may prove possible to further refine such antibody engineering to selectively engage activating, as opposed to inhibitory $\mathrm{F} c \gamma$ receptors. Antibody structures can be further modified to contain immunostimulatory motifs that selectively induce and amplify antigen presentation to favor the induction of clinically effective host anti-tumor immunity. ${ }^{161}$ In lieu of direct modification of antibody structures, anti-tumor antibodies might also be combined with other agents that promote antigen presentation (e.g., toll receptor agonists), or overcome negative regulation (e.g., anti-CTLA-4 antibody). It is worth noting that several clinically useful antibodies are routinely combined with chemotherapy agents; ${ }^{162,163}$ further studies are required to determine if chemotherapy-based tumor destruction cooperates with monoclonal antibody therapy to promote adaptive, tumor antigen-specific immunity.

\section{Summary}

DCs are critical APCs to initiate and regulate immunity. A growing body of evidence now suggests that these cells also play an important role in shaping the host response to tumors. Interactions between DCs and dying cells are determined by a balance of several (often opposing) molecular interactions that regulate recognition, uptake, processing and ultimately presentation of cellular antigens to the immune system. DCs also interact with living tumor cells and have non-immunologic effects on tumor cells and their microenvironment. The interactions between tumor cells and subsets of DCs are complex and just beginning to be understood. Improved understanding of the interactions between DCs and tumors will provide fundamental insights into the mechanisms of tumor immune surveillance and escape, and yield novel approaches to therapy of cancer.

Acknowledgements. MVD is supported in part by funds from the National Institutes of Health (NIH; CA106802, CA109465 AT02779), Damon Runyon Cancer Research Fund, Dana Foundation, and Irma T Hirschl Foundation. KMD is supported in part by funds from the NIH (Al054375) and the Dana Foundation. AKP is supported in part by funds from the NIH (P01 CA084514, R01 CA089440 and CA078846), the Dana Foundation, the Susan Komen Foundation, the Baylor Health Care System and the Baylor Health Care System Foundation. This manuscript is dedicated to all of our patients and volunteers who have participated in our studies and clinical trials. MVD and KMD thank Dr. Ralph Steinman for his mentorship. AKP thanks Dr. Jacques Banchereau for mentorship; former and current members of the BIIR for their contributions; Dr. Carson Harrod and Cindy Samuelsen for continuous help; Dr. Michael Ramsay and Dr. William Duncan for their continuous support. AKP holds the Michael A. Ramsay Chair for Cancer Immunology Research.

1. Bissell MJ, Radisky D. Putting tumours in context. Nat Rev Cancer 2001; 1: 46-54

2. Pardoll D. Does the immune system see tumors as foreign or self? Annu Rev Immunol 2003; 21: 807-839.

3. Banchereau J, Briere F, Caux C, Davoust J, Lebecque S, Liu YJ et al. Immunobiology of dendritic cells. Annu Rev Immunol 2000; 18: 767-811.

4. Savill J, Dransfield I, Gregory C, Haslett C. A blast from the past: clearance of apoptotic cells regulates immune responses. Nat Rev Immunol 2002; 2: 965-975.

5. Aspord C, Pedroza-Gonzalez A, Gallegos M, Tindle S, Burton EC, Su D et al. Breast cancer instructs dendritic cells to prime interleukin 13-secreting CD4+ T cells that facilitate tumor development. J Exp Med 2007; 204: 1037-1047.

6. Rettig MB, Ma HJ, Vescio RA, Pold M, Schiller G, Belson D et al. Kaposi's sarcomaassociated herpesvirus infection of bone marrow dendritic cells from multiple myeloma patients. Science 1997; 276: 1851-1854.

7. Bell D, Chomarat P, Broyles D, Netto G, Harb GM, Lebecque S et al. In breast carcinoma tissue, immature dendritic cells reside within the tumor, whereas mature dendritic cells are located in peritumoral areas. J Exp Med 1999; 190: 1417-1426.

8. Mantovani A, Sozzani S, Locati M, Schioppa T, Saccani A, Allavena P et al. Infiltration of tumours by macrophages and dendritic cells: tumour-associated macrophages as a paradigm for polarized M2 mononuclear phagocytes. Novartis Found Symp 2004; 256: 137-145; discussion 146-148, 259-269.

9. Steinman RM, Hawiger D, Liu K, Bonifaz L, Bonnyay D, Mahnke K et al. Dendritic cell function in vivo during the steady state: a role in peripheral tolerance. Ann NY Acad Sci 2003; 987: 15-25.

10. Hawiger D, Inaba K, Dorsett Y, Guo M, Mahnke K, Rivera M et al. Dendritic cells induce peripheral T cell unresponsiveness under steady state conditions in vivo. J Exp Med 2001; 194: 769-779.

11. Banchereau J, Steinman RM. Dendritic cells and the control of immunity. Nature 1998; 392: 245-252.

12. Liu K, Idoyaga J, Charalambous A, Fujii S, Bonito A, Mordoh J et al. Innate NKT lymphocytes confer superior adaptive immunity via tumor-capturing dendritic cells. J Exp Med 2005; 202: 1507-1516. 
13. Bonifaz LC, Bonnyay DP, Charalambous A, Darguste DI, Fujii S, Soares $\mathrm{H}$ et al. In vivo targeting of antigens to maturing dendritic cells via the DEC-205 receptor improves $T$ cell vaccination. J Exp Med 2004; 199: 815-824.

14. Mellman I, Steinman RM. Dendritic cells: specialized and regulated antigen processing machines. Cell 2001; 106: 255-258.

15. Steinman RM. Linking innate to adaptive immunity through dendritic cells. Novartis Found Symp 2006; 279: 101-109; discussion 109-113, 216-219.

16. Schoenberger SP, Toes RE, van der Voort El, Offringa R, Melief CJ. T-cell help for cytotoxic T lymphocytes is mediated by CD40-CD40L interactions. Nature 1998; 393 480-483.

17. Macagno A, Napolitani G, Lanzavecchia A, Sallusto F. Duration, combination and timing: the signal integration model of dendritic cell activation. Trends Immunol 2007; 28 : 227-233.

18. Sporri R, Reis e Sousa C. Inflammatory mediators are insufficient for full dendritic cell activation and promote expansion of $\mathrm{CD} 4+\mathrm{T}$ cell populations lacking helper function. $\mathrm{Nat}$ Immunol 2005; 6: 163-170.

19. Fujii S, Liu K, Smith C, Bonito AJ, Steinman RM. The linkage of innate to adaptive immunity via maturing dendritic cells in vivo requires $C D 40$ ligation in addition to antigen presentation and CD80/86 costimulation. J Exp Med 2004; 199: 1607-1618.

20. Huang AYC, Golumbek P, Ahmadzadeh M, Jaffee E, Pardoll D, Levitsky H. Role of bone marrow-derived cells in presenting MHC class I-restricted tumor antigens. Science 1994; 264: 961-965.

21. Albert ML, Sauter B, Bhardwaj N. Dendritic cells acquire antigen from apoptotic cells and induce class I-restricted CTLs. Nature 1998; 392: 86-89.

22. Heath WR, Belz GT, Behrens GM, Smith CM, Forehan SP, Parish IA et al. Crosspresentation, dendritic cell subsets, and the generation of immunity to cellular antigens. Immunol Rev 2004; 199: 9-26.

23. Steinman RM, Hawiger D, Nussenzweig MC. Tolerogenic dendritic cells. Annu Rev Immunol 2003; 21: 685-711.

24. Gaipl US, Sheriff A, Franz S, Munoz LE, Voll RE, Kalden JR et al. Inefficient clearance of dying cells and autoreactivity. Curr Top Microbiol Immunol 2006; 305: 161-176.

25. Jonuleit $H$, Schmitt $E$, Schuler G, Knop J, Enk AH. Induction of interleukin 10-producing nonproliferating $\mathrm{CD} 4(+) \mathrm{T}$ cells with regulatory properties by repetitive stimulation with allogeneic immature human dendritic cells. J Exp Med 2000; 192: 1213-1222.

26. Dhodapkar MV, Steinman RM, Krasovsky J, Munz C, Bhardwaj N. Antigen specific inhibition of effector $T$ cell function in humans after injection of immature dendritic cells. J Exp Med 2001; 193: 233-238.

27. Yamazaki S, lyoda T, Tarbell K, Olson K, Velinzon K, Inaba K et al. Direct expansion of functional CD25+ CD4+ regulatory $T$ cells by antigen-processing dendritic cells. $J$ Exp Med 2003; 198: 235-247.

28. Tarbell KV, Yamazaki S, Olson K, Toy P, Steinman RM. CD25+ CD4+ T cells, expanded with dendritic cells presenting a single autoantigenic peptide, suppress autoimmune diabetes. J Exp Med 2004; 199: 1467-1477.

29. Banerjee D, Dhodapkar MV, Matayeva E, Steinman RM, Dhodapkar K. Expansion of FOXP3high regulatory $T$ cells by human dendritic cells (DCs) in vitro and after DC injection of cytokine matured DCs in myeloma patients. Blood 2006; 108: 2655-2661.

30. Suffia IJ, Reckling SK, Piccirillo CA, Goldszmid RS, Belkaid Y Infected site-restricted Foxp3+ natural regulatory $T$ cells are specific for microbial antigens. J Exp Med 2006 203: $777-788$.

31. Luo X, Tarbell KV, Yang H, Pothoven K, Bailey SL, Ding R et al. Dendritic cells with TGFbeta1 differentiate naive $C D 4+C D 25-T$ cells into islet-protective Foxp3+ regulatory $T$ cells. Proc Natl Acad Sci USA 2007; 104: 2821-2826.

32. Levings MK, Bacchetta R, Schulz U, Roncarolo MG. The role of IL-10 and TGF-beta in the differentiation and effector function of T regulatory cells. Int Arch Allergy Immunol 2002; 129: 263-276.

33. Zou W. Immunosuppressive networks in the tumour environment and their therapeutic relevance. Nat Rev Cancer 2005; 5: 263-274.

34. Zou W. Regulatory T cells, tumour immunity and immunotherapy. Nat Rev Immuno/ 2006; 6: 295-307.

35. Pulendran B, Palucka K, Banchereau J. Sensing pathogens and tuning immune responses. Science 2001; 293: 253-256.

36. Ferlazzo G, Munz C. NK cell compartments and their activation by dendritic cells. J Immunol 2004; 172: 1333-1339.

37. Steinman RM, Dhodapkar M. Active immunization against cancer with dendritic cells: the near future. Int J Cancer 2001; 94: 459-473.

38. Banchereau J, Palucka AK. Dendritic cells as therapeutic vaccines against cancer. Nat Rev Immunol 2005; 5: 296-306.

39. Zitvogel L, Casares N, Pequignot MO, Chaput N, Albert ML, Kroemer G. Immune response against dying tumor cells. Adv Immunol 2004; 84: 131-179.

40. Lauber K, Bohn E, Krober SM, Xiao YJ, Blumenthal SG, Lindemann RK et al. Apoptotic cells induce migration of phagocytes via caspase-3-mediated release of a lipid attraction signal. Cell 2003; 113: 717-730.

41. Fadok VA, Bratton DL, Frasch SC, Warner ML, Henson PM. The role of phosphatidylserine in recognition of apoptotic cells by phagocytes. Cell Death Differ 1998; 5: 551-562.

42. Fadok VA, Bratton DL, Henson PM. Phagocyte receptors for apoptotic cells: recognition, uptake, and consequences. J Clin Invest 2001; 108: 957-962.
43. Albert ML, Pearce SF, Francisco LM, Sauter B, Roy P, Silverstein RL et al. Immature dendritic cells phagocytose apoptotic cells via alphavbeta5 and CD36, and cross-presen antigens to cytotoxic T lymphocytes. J Exp Med 1998; 188: 1359-1368.

44. Scott RS, McMahon EJ, Pop SM, Reap EA, Caricchio R, Cohen PL et al. Phagocytosis and clearance of apoptotic cells is mediated by MER. Nature 2001; 411 207-211.

45. Gardai SJ, McPhillips KA, Frasch SC, Janssen WJ, Starefeldt A, Murphy-Ullrich JE et al. Cell-surface calreticulin initiates clearance of viable or apoptotic cells through transactivation of LRP on the phagocyte. Cell 2005; 123: 321-334.

46. Brown S, Heinisch I, Ross E, Shaw K, Buckley CD, Savill J. Apoptosis disables CD31mediated cell detachment from phagocytes promoting binding and engulfment. Nature 2002; 418: 200-203.

47. Regnault A, Lankar D, Lacabanne V, Rodriguez A, Thery C, Rescigno M et al. Fcgamma receptor-mediated induction of dendritic cell maturation and major histocompatibility complex class I-restricted antigen presentation after immune complex internalization. J Exp Med 1999; 189: 371-380.

48. Skoberne M, Somersan S, Almodovar W, Truong T, Petrova K, Henson PM et al. The apoptotic-cell receptor $\mathrm{CR} 3$, but not alphavbeta5, is a regulator of human dendritic-cell immunostimulatory function. Blood 2006; 108: 947-955.

49. Behrens EM, Sriram U, Shivers DK, Gallucci M, Ma Z, Finkel TH et al. Complement receptor 3 ligation of dendritic cells suppresses their stimulatory capacity. J Immunol 2007; 178: 6268-6279.

50. Sen $P$, Wallet MA, Yi Z, Huang Y, Henderson M, Mathews CE et al. Apoptotic cells induce Mer tyrosine kinase-dependent blockade of NF-kappaB activation in dendritic cells. Blood 2007; 109: 653-660.

51. Blander JM, Medzhitov R. Regulation of phagosome maturation by signals from toll-like receptors. Science 2004; 304: 1014-1018.

52. Yates RM, Russell DG. Phagosome maturation proceeds independently of stimulation of toll-like receptors 2 and 4. Immunity 2005; 23: 409-417.

53. Blander JM, Medzhitov R. On regulation of phagosome maturation and antigen presentation. Nat Immunol 2006; 7: 1029-1035.

54. Blander JM, Medzhitov R. Toll-dependent selection of microbial antigens for presentation by dendritic cells. Nature 2006; 440: 808-812.

55. Dhodapkar KM, Kaufman JL, Ehlers M, Banerjee DK, Bonvini E, Koenig S et al. Selective blockade of inhibitory Fc gamma receptor enables human dendritic cell maturation with IL12 p70 production and immunity to antibody-coated tumor cells. Proc Natl Acad Sci USA 2005; 102: 2910-2915.

56. Kalergis AM, Ravetch JV. Inducing tumor immunity through the selective engagement of activating Fc receptors on dendritic cells. J Exp Med 2002; 195: 1653-1659.

57. Geijtenbeek TB, van Vliet SJ, Engering A, t Hart BA, van Kooyk Y. Self- and nonself-recognition by C-type lectins on dendritic cells. Annu Rev Immunol 2004; 22 33-54

58. Bonifaz L, Bonnyay D, Mahnke K, Rivera M, Nussenzweig MC, Steinman RM. Efficient targeting of protein antigen to the dendritic cell receptor DEC-205 in the steady state leads to antigen presentation on major histocompatibility complex class I products and peripheral CD8+ T cell tolerance. J Exp Med 2002; 196: 1627-1638.

59. Akakura S, Singh S, Spataro M, Akakura R, Kim JI, Albert ML et al. The opsonin MFG-E8 is a ligand for the alphavbeta5 integrin and triggers DOCK180-dependent Rac1 activation for the phagocytosis of apoptotic cells. Exp Cell Res 2004; 292: 403-416.

60. Ishimoto Y, Ohashi K, Mizuno K, Nakano T. Promotion of the uptake of PS liposomes and apoptotic cells by a product of growth arrest-specific gene, gas6. J Biochem (Tokyo) 2000; 127: 411-417.

61. Korb LC, Ahearn JM. C1q binds directly and specifically to surface blebs of apoptotic human keratinocytes: complement deficiency and systemic lupus erythematosus revisited. J Immunol 1997; 158: 4525-4528.

62. Ogden CA, deCathelineau A, Hoffmann PR, Bratton D, Ghebrehiwet B, Fadok VA et al. C1q and mannose binding lectin engagement of cell surface calreticulin and CD9 initiates macropinocytosis and uptake of apoptotic cells. J Exp Med 2001; 194: 781-795.

63. Vandivier RW, Ogden CA, Fadok VA, Hoffmann PR, Brown KK, Botto $M$ et al. Role of surfactant proteins $\mathrm{A}, \mathrm{D}$, and $\mathrm{C} 1 \mathrm{q}$ in the clearance of apoptotic cells in vivo and in vitro: calreticulin and CD91 as a common collectin receptor complex. J Immunol 2002; 169: 3978-3986.

64. Verbovetski I, Bychkov H, Trahtemberg U, Shapira I, Hareuveni M, Ben-Tal O et al. Opsonization of apoptotic cells by autologous iC3b facilitates clearance by immature dendritic cells, down-regulates DR and CD86, and up-regulates CC chemokine receptor 7. J Exp Med 2002; 196: 1553-1561.

65. Mevorach D, Mascarenhas JO, Gershov D, Elkon KB. Complement-dependent clearance of apoptotic cells by human macrophages. J Exp Med 1998; 188: 2313-2320.

66. Hanayama R, Tanaka M, Miwa K, Shinohara A, Iwamatsu A, Nagata S. Identification of a factor that links apoptotic cells to phagocytes. Nature 2002; 417: 182-187.

67. Anderson HA, Maylock CA, Williams JA, Paweletz CP, Shu H, Shacter E. Serum-derived protein $S$ binds to phosphatidylserine and stimulates the phagocytosis of apoptotic cells Nat Immunol 2003; 4: 87-91.

68. Leverrier Y, Ridley AJ. Requirement for Rho GTPases and PI 3-kinases during apoptotic cell phagocytosis by macrophages. Curr Biol 2001; 11: 195-199.

69. Trombetta ES, Mellman I. Cell biology of antigen processing in vitro and in vivo. Annu Rev mmunol 2005; 23: 975-1028. 
70. Delamarre L, Pack M, Chang H, Mellman I, Trombetta ES. Differential lysosomal proteolysis in antigen-presenting cells determines antigen fate. Science 2005; 307 1630-1634.

71. Trombetta ES, Ebersold M, Garrett W, Pypaert M, Mellman I. Activation of lysosomal function during dendritic cell maturation. Science 2003; 299: 1400-1403.

72. Delamarre L, Couture R, Mellman I, Trombetta ES. Enhancing immunogenicity by limiting susceptibility to lysosomal proteolysis. J Exp Med 2006; 203: 2049-2055.

73. Heath WR, Carbone FR. Cross-presentation, dendritic cells, tolerance and immunity. Annu Rev Immunol 2001; 19: 47-64.

74. Krispin A, Bledi Y, Atallah M, Trahtemberg U, Verbovetski I, Nahari E et al. Apoptotic cell thrombospondin-1 and heparin-binding domain lead to dendritic-cell phagocytic and tolerizing states. Blood 2006; 108: 3580-3589.

75. Lemke G, Lu Q. Macrophage regulation by Tyro 3 family receptors. Curr Opin Immunol 2003; 15: 31-36.

76. Cohen PL, Caricchio R, Abraham V, Camenisch TD, Jennette JC, Roubey RA et al. Delayed apoptotic cell clearance and lupus-like autoimmunity in mice lacking the c-me membrane tyrosine kinase. J Exp Med 2002; 196: 135-140.

77. Chen J, Carey K, Godowski PJ. Identification of Gas6 as a ligand for Mer, a neural cell adhesion molecule related receptor tyrosine kinase implicated in cellular transformation. Oncogene 1997; 14: 2033-2039.

78. Ravetch JV, Bolland S. IgG Fc receptors. Annu Rev Immunol 2001; 19: 275-290.

79. Ravetch JV. A full complement of receptors in immune complex diseases. J Clin Invest 2002; 110: 1759-1761.

80. Dhodapkar KM, Krasovsky J, Williamson B, Dhodapkar MV. Antitumor monoclonal antibodies enhance cross-presentation of cellular antigens and the generation of myeloma-specific killer T cells by dendritic cells. J Exp Med 2002; 195: 125-133.

81. Groh V, Li YQ, Cioca D, Hunder NN, Wang W, Riddell SR et al. Efficient cross-priming of tumor antigen specific $T$ cells by dendritic cells sensitized with diverse anti-MICA opsonized tumor cells. Proc Natl Acad Sci USA 2005; 102: 6461-6466.

82. Dhodapkar KM, Dhodapkar MV. Recruiting dendritic cells to improve antibody therapy of cancer. Proc Natl Acad Sci USA 2005; 102: 6243-6244.

83. Sedlik C, Orbach D, Veron P, Schweighoffer E, Colucci F, Gamberale R et al. A critica role for Syk protein tyrosine kinase in $\mathrm{Fc}$ receptor-mediated antigen presentation and induction of dendritic cell maturation. J Immunol 2003; 170: 846-852.

84. Dhodapkar KM, Banerjee D, Connolly J, Kukreja A, Matayeva E, Veri MC et al. Selective blockade of the inhibitory Fc\{gamma\} receptor (Fc\{gamma\}RIIB) in human dendritic cells and monocytes induces a type I interferon response program. J Exp Med 2007; 204: 1359-1369.

85. Robinson MJ, Sancho D, Slack EC, LeibundGut-Landmann S, Reis e Sousa C. Myeloid C-type lectins in innate immunity. Nat Immunol 2006; 7: 1258-1265

86. Geijtenbeek TB, Van Vliet SJ, Koppel EA, Sanchez-Hernandez M, VandenbrouckeGrauls CM, Appelmelk B et al. Mycobacteria target DC-SIGN to suppress dendritic cell function. J Exp Med 2003; 197: 7-17.

87. Leibundgut-Landmann S, Gross O, Robinson MJ, Osorio F, Slack EC, Tsoni SV et al. Syk- and CARD9-dependent coupling of innate immunity to the induction of $T$ helper cells that produce interleukin 17. Nat Immunol 2007; 8: 630-638

88. Saeland E, van Vliet SJ, Backstrom M, van den Berg VC, Geijtenbeek TB, Meijer GA et al. The C-type lectin MGL expressed by dendritic cells detects glycan changes on MUC1 in colon carcinoma. Cancer Immunol Immunother 2007; 56: 1225-1236.

89. van Gisbergen KP, Aarnoudse CA, Meijer GA, Geijtenbeek TB, van Kooyk Y. Dendritic cells recognize tumor-specific glycosylation of carcinoembryonic antigen on colorectal cancer cells through dendritic cell-specific intercellular adhesion molecule-3-grabbing nonintegrin. Cancer Res 2005; 65: 5935-5944.

90. Medzhitov R. Toll-like receptors and innate immunity. Nat Rev Immunol 2001; 1 135-145.

91. Underhill DM, Ozinsky A, Hajjar AM, Stevens A, Wilson CB, Bassetti M et al. The Toll-like receptor 2 is recruited to macrophage phagosomes and discriminates between pathogens. Nature 1999; 401: 811-815.

92. Gantner BN, Simmons RM, Canavera SJ, Akira S, Underhill DM. Collaborative induction of inflammatory responses by dectin-1 and Toll-like receptor 2. J Exp Med 2003; 197 1107-1117.

93. Pierre P, Turley SJ, Gatti E, Hull M, Meltzer J, Mirza A et al. Developmental regulation of MHC class II transport in mouse dendritic cells (see comments). Nature 1997; 388 . 787-792.

94. Jancic C, Savina A, Wasmeier C, Tolmachova T, El-Benna J, Dang PM et al. Rab27a regulates phagosomal $\mathrm{pH}$ and NADPH oxidase recruitment to dendritic cell phagosomes. Nat Cell Biol 2007; 9: 367-378.

95. Savina A, Jancic C, Hugues S, Guermonprez P, Vargas P, Moura IC et al. NOX2 controls phagosomal $\mathrm{pH}$ to regulate antigen processing during crosspresentation by dendritic cells. Cell 2006; 126: 205-218.

96. Schulz O, Diebold SS, Chen M, Naslund TI, Nolte MA, Alexopoulou L et al. Toll-like receptor 3 promotes cross-priming to virus-infected cells. Nature 2005; 433: 887-892.

97. Wille-Reece U, Flynn BJ, Lore K, Koup RA, Miles AP, Saul A et al. Toll-like receptor agonists influence the magnitude and quality of memory $T$ cell responses after primeboost immunization in nonhuman primates. J Exp Med 2006; 203: 1249-1258.

98. Kim S, Elkon KB, Ma X. Transcriptional suppression of interleukin-12 gene expression following phagocytosis of apoptotic cells. Immunity 2004; 21: 643-653.
99. Henson PM, Hume DA. Apoptotic cell removal in development and tissue homeostasis. Trends Immunol 2006; 27: 244-250.

100. Matzinger P. Tolerance, danger, and the extended family. Annu Rev Immunol 1994; 12 : 991-1045.

101. Scaffidi $P$, Misteli T, Bianchi ME. Release of chromatin protein HMGB1 by necrotic cells triggers inflammation. Nature 2002; 418: 191-195.

102. Somersan S, Larsson M, Fonteneau JF, Basu S, Srivastava P, Bhardwaj N. Primary tumor tissue lysates are enriched in heat shock proteins and induce the maturation of human dendritic cells. J Immunol 2001; 167: 4844-4852.

103. Shi Y, Evans JE, Rock KL. Molecular identification of a danger signal that alerts the immune system to dying cells. Nature 2003; 425: 516-521.

104. Scheibner KA, Lutz MA, Boodoo S, Fenton MJ, Powell JD, Horton MR. Hyaluronan fragments act as an endogenous danger signal by engaging TLR2. J Immunol 2006; 177 : 1272-1281.

105. Lamkanfi M, Kanneganti TD, Franchi L, Nunez G. Caspase-1 inflammasomes in infection and inflammation. J Leukoc Biol 2007; 82: 220-225

106. Martinon F, Tschopp J. Inflammatory caspases: linking an intracellular innate immune system to autoinflammatory diseases. Cell 2004; 117: 561-574.

107. Martinon F, Petrilli V, Mayor A, Tardivel A, Tschopp J. Gout-associated uric acid crystals activate the NALP3 inflammasome. Nature 2006; 440: 237-241.

108. Chen CJ, Kono H, Golenbock D, Reed G, Akira S, Rock KL. Identification of a key pathway required for the sterile inflammatory response triggered by dying cells. Nat $\mathrm{Med}$ 2007; 13: 851-856.

109. Apetoh L, Ghiringhelli F, Tesniere A, Obeid M, Ortiz C, Criollo A et al. Toll-like receptor 4dependent contribution of the immune system to anticancer chemotherapy and radiotherapy. Nat Med 2007; 13: 1050-1059.

110. Tian J, Avalos AM, Mao SY, Chen B, Senthil K, Wu H et al. Toll-like receptor 9-dependent activation by DNA-containing immune complexes is mediated by HMGB1 and RAGE. Nat Immunol 2007; 8: 487-496.

111. Hu X, Chen J, Wang L, Ivashkiv LB. Crosstalk among Jak-STAT, Toll-like receptor, and ITAM-dependent pathways in macrophage activation. J Leukoc Biol 2007; 82: 237-243.

112. Tassiulas I, Park-Min KH, Hu Y, Kellerman L, Mevorach D, Ivashkiv LB. Apoptotic cells inhibit LPS-induced cytokine and chemokine production and IFN responses in macrophages. Hum Immunol 2007; 68: 156-164.

113. Cheng F, Wang HW, Cuenca A, Huang M, Ghansah T, Brayer J et al. A critical role for Stat3 signaling in immune tolerance. Immunity 2003; 19: 425-436.

114. Banchereau J, Paczesny S, Blanco P, Bennett L, Pascual V, Fay J et al. Dendritic cells: controllers of the immune system and a new promise for immunotherapy. Ann NY Acad Sci 2003; 987: 180-187.

115. Janssen E, Tabeta K, Barnes MJ, Rutschmann S, McBride S, Bahjat KS et al. Efficient T cell activation via a Toll-Interleukin 1 Receptor-independent pathway. Immunity 2006; 24 : 787-799.

116. Dudziak D, Kamphorst AO, Heidkamp GF, Buchholz VR, Trumpfheller C, Yamazaki S et al. Differential antigen processing by dendritic cell subsets in vivo. Science 2007; 315 : 107-111.

117. den Haan JM, Bevan MJ. Constitutive versus activation dependent cross presentation of immune complexes by CD8+ and CD8 - dendritic cells in vivo. J Exp Med 2002; 196: 817-827.

118. den Haan JM, Lehar SM, Bevan MJ. CD8(+) but not CD8(-) dendritic cells cross-prime cytotoxic T cells in vivo. J Exp Med 2000; 192: 1685-1696.

119. Shortman K, Liu YJ. Mouse and human dendritic cell subtypes. Nat Rev Immunol 2002; 2: $151-161$.

120. Valladeau J, Saeland S. Cutaneous dendritic cells. Semin Immunol 2005; 17 : 273-283.

121. Caux C, Dezutter-Dambuyant C, Schmitt D, Banchereau J. GM-CSF and TNF- $\alpha$ cooperate in the generation of dendritic Langerhans cells. Nature 1992; 360: 258-261.

122. Caux C, Massacrier C, Vanbervliet B, Dubois B, Durand I, Cella M et al. CD34 ${ }^{+}$ hematopoietic progenitors from human cord blood differentiate along two independent dendritic cell pathways in response to granulocyte-macrophage colony-stimulating factor plus tumor necrosis factor $\alpha$. Blood 1997; 90: 1458-1470.

123. Dubois B, Bridon JM, Fayette J, Barthelemy C, Banchereau J, Caux C et al. Dendritic cells directly modulate B cell growth and differentiation. J Leukoc Biol 1999; 66: 224-230.

124. Romani N, Reider D, Heuer M, Ebner S, Eibl B, Niederwieser D et al. Generation of mature dendritic cells from human blood: an improved method with special regard to clinical applicability. J Immunol Meth 1996; 196: 137-151.

125. Paquette RL, Hsu NC, Kiertscher SM, Park AN, Tran L, Roth MD et al. Interferon-alpha and granulocyte-macrophage colony-stimulating factor differentiate peripheral blood monocytes into potent antigen-presenting cells. J Leukoc Biol 1998; 64: 358-367.

126. Gilliet M, Soumelis V, Watanabe N, Hanabuchi S, Antonenko S, de Waal-Malefyt R et al. Human dendritic cells activated by TSLP and CD40L induce proallergic cytotoxic T cells. J Exp Med 2003; 197: 1059-1063.

127. Soumelis V, Reche PA, Kanzler H, Yuan W, Edward G, Homey B et al. Human epithelial cells trigger dendritic cell mediated allergic inflammation by producing TSLP. Nat Immunol 2002; 3: 673-680

128. Mohamadzadeh M, Berard F, Essert G, Chalouni C, Pulendran B, Davoust J et al. Interleukin 15 skews monocyte differentiation into dendritic cells with features of Langerhans cells. J Exp Med 2001; 194: 1013-1020. 
129. Dubsky P, Saito H, Leogier M, Dantin C, Connolly JE, Banchereau J et al. IL-15-induced human DC efficiently prime melanoma-specific naive CD8+ T cells to differentiate into CTL. Eur J Immunol 2007; 37: 1678-1690.

130. Blanco P, Palucka AK, Gill M, Pascual V, Banchereau J. Induction of dendritic cell differentiation by IFN-alpha in systemic lupus erythematosus. Science 2001; 294: 1540-1543.

131. Harshyne LA, Watkins SC, Gambotto A, Barratt-Boyes SM. Dendritic cells acquire antigens from live cells for cross-presentation to CTL. $J$ Immunol 2001; 166 : 3717-3723.

132. Harshyne LA, Zimmer MI, Watkins SC, Barratt-Boyes SM. A role for class A scavenger receptor in dendritic cell nibbling from live cells. J Immunol 2003; 170: 2302-2309.

133. Ghiringhelli F, Puig PE, Roux S, Parcellier A, Schmitt E, Solary E et al. Tumor cells convert immature myeloid dendritic cells into TGF-beta-secreting cells inducing CD4+CD25+ regulatory T cell proliferation. J Exp Med 2005; 202: 919-929.

134. Kukreja A, Hutchinson A, Mazumder A, Vesole D, Angitapalli R, Jagannath $S$ et al. Bortezomib disrupts tumour-dendritic cell interactions in myeloma and lymphoma: therapeutic implications. Br J Haematol 2007; 136: 106-110.

135. Kukreja A, Hutchinson A, Dhodapkar K, Mazumder A, Vesole D, Angitapalli R et al. Enhancement of clonogenicity of human multiple myeloma by dendritic cells. J Exp Med 2006; 203: 1859-1865.

136. Bahlis NJ, King AM, Kolonias D, Carlson LM, Liu HY, Hussein MA et al. CD28-mediated regulation of multiple myeloma cell proliferation and survival. Blood 2007; 109: 5002-5010.

137. Coukos G, Benencia F, Buckanovich RJ, Conejo-Garcia JR. The role of dendritic cell precursors in tumour vasculogenesis. Br J Cancer 2005; 92: 1182-1187.

138. Curiel TJ, Cheng P, Mottram P, Alvarez X, Moons L, Evdemon-Hogan M et al. Dendritic cell subsets differentially regulate angiogenesis in human ovarian cancer. Cancer Res 2004; 64: 5535-5538.

139. Stary G, Bangert C, Tauber M, Strohal R, Kopp T, Stingl G. Tumoricidal activity of TLR7/8activated inflammatory dendritic cells. J Exp Med 2007; 204: 1441-1451.

140. Spits H, Lanier LL. Natural killer or dendritic: what's in a name? Immunity 2007; 26 : $11-16$.

141. Ghiringhelli F, Apetoh L, Housseau F, Kroemer G, Zitvogel L. Links between innate and cognate tumor immunity. Curr Opin Immunol 2007; 19: 224-231.

142. Taieb J, Chaput N, Menard C, Apetoh L, Ullrich E, Bonmort M et al. A novel dendritic cell subset involved in tumor immunosurveillance. Nat Med 2006; 12: 214-219.

143. Chan CW, Crafton E, Fan HN, Flook J, Yoshimura K, Skarica M et al. Interferon-producing killer dendritic cells provide a link between innate and adaptive immunity. Nat Med 2006; 12: 207-213.

144. Huang J, Tatsumi T, Pizzoferrato E, Vujanovic N, Storkus WJ. Nitric oxide sensitizes tumor cells to dendritic cell-mediated apoptosis, uptake, and cross-presentation. Cancer Res 2005; 65: 8461-8470.

145. Casares N, Pequignot MO, Tesniere A, Ghiringhelli F, Roux S, Chaput N et al. Caspasedependent immunogenicity of doxorubicin-induced tumor cell death. J Exp Med 2005; 202: 1691-1701.
146. Obeid M, Tesniere A, Ghiringhelli F, Fimia GM, Apetoh L, Perfettini JL et al. Calreticulin exposure dictates the immunogenicity of cancer cell death. Nat Med 2007; 13: 54-61.

147. Spisek R, Charalambous A, Mazumder A, Vesole DH, Jagannath S, Dhodapkar MV. Bortezomib enhances dendritic cell (DC) mediated induction of immunity to human myeloma via exposure of cell surface heat shock protein 90 on dying tumor cells: therapeutic implications. Blood 2007; 109 (Jun 1): 4839-4845.

148. Spisek R, Dhodapkar MV. Towards a better way to die with chemotherapy: role of heat shock protein exposure on dying tumor cells. Cell Cycle 2007; in: press.

149. Demaria S, Santori FR, Ng B, Liebes L, Formenti SC, Vukmanovic S. Select forms of tumor cell apoptosis induce dendritic cell maturation. J Leukoc Biol 2005; 77: 361-368.

150. Lee KP, Raez LE, Podack ER. Heat shock protein-based cancer vaccines. Hematol Oncol Clin North Am 2006; 20: 637-659.

151. Shi H, Cao T, Connolly JE, Monnet L, Bennett L, Chapel S et al. Hyperthermia enhances CTL cross-priming. J Immunol 2006; 176: 2134-2141.

152. Masse D, Ebstein F, Bougras G, Harb J, Meflah K, Gregoire M. Increased expression of inducible HSP70 in apoptotic cells is correlated with their efficacy for antitumor vaccine therapy. Int J Cancer 2004; 111: 575-583.

153. Liu B, Dai J, Zheng H, Stoilova D, Sun S, Li Z. Cell surface expression of an endoplasmic reticulum resident heat shock protein gp96 triggers MyD88-dependent systemic autoimmune diseases. Proc Natl Acad Sci USA 2003; 100: 15824-15829.

154. Dai J, Liu B, Caudill MM, Zheng H, Qiao Y, Podack ER et al. Cell surface expression of heat shock protein gp96 enhances cross-presentation of cellular antigens and the generation of tumor-specific T cell memory. Cancer Immun 2003; 3: 1.

155. Gerecitano J, Goy A, Wright J, MacGregor-Cortelli B, Neylon E, Gonen M et al. Druginduced cutaneous vasculitis in patients with non-Hodgkin lymphoma treated with the novel proteasome inhibitor bortezomib: a possible surrogate marker of response? $\mathrm{Br} \mathrm{J}$ Haematol 2006; 134: 391-398.

156. Lake RA, Robinson BW. Immunotherapy and chemotherapy - a practical partnership. Nat Rev Cancer 2005; 5: 397-405.

157. Spisek R, Kukreja A, Chen LC, Matthews P, Mazumder A, Vesole D et al. Frequent and specific immunity to the embryonal stem cell-associated antigen SOX2 in patients with monoclonal gammopathy. J Exp Med 2007; 204: 831-840.

158. Clynes R. Antitumor antibodies in the treatment of cancer: Fc receptors link opsonic antibody with cellular immunity. Hematol Oncol Clin North Am 2006; 20: 585-612.

159. Adams GP, Weiner LM. Monoclonal antibody therapy of cancer. Nat Biotechnol 2005; 23: 1147-1157.

160. Weiner LM, Carter P. Tunable antibodies. Nat Biotechnol 2005; 23: 556-557.

161. Bowles JA, Wang SY, Link BK, Allan B, Beuerlein G, Campbell MA et al. Anti-CD20 monoclonal antibody with enhanced affinity for CD16 activates NK cells at lower concentrations and more effectively than rituximab. Blood 2006; 108: 2648-2654.

162. Weiner GJ, Link BK. Antibody therapy of lymphoma. Adv Pharmacol 2004; 51: 229-253.

163. Levy R. A perspective on monoclonal antibody therapy: where we have been and where we are going. Semin Hematol 2000; 37 (4 Suppl 7): 43-46.

164. Itano AA, Jenkins MK. Antigen presentation to naive CD4T cells in the lymph node. Nat Immunol 2003; 4: 733-739. 